\title{
PERBEDAAN STATUS GIZI BAYI BERUMUR 4-6 BULAN PADA PEMBERIAN ASI EKSKLUSIF DENGAN ASI NON EKSKLUSIF
}

\author{
THE DIFFERENCE IN NUTRITIONAL STATUS BETWEEN INFANTS AGED 4-6 MONTHS \\ ON EXCLUSIVE BREASTFEEDING AND NON-EXCLUSIVE BREASTFEEDING
}

\author{
Mira Candra Karuniawati, M.Shoim Dasuki, Anika Candrasari \\ Fakultas Kedokteran Universitas Muhammadiyah Surakarta \\ Korespondensi: dr. M.Shoim Dasuki,MKes, Email: mohammad.dasuki@ums.id
}

\begin{abstract}
ABSTRAK
Cakupan pemberian ASI eksklusif di Indonesia hanya 42\%. Survey tahun 2013, menemukan sekitar 19,6\% balita Indonesia menderita kekurangan gizi. Tujuan penelitian ini adalah untuk mengetahui perbedaan status gizi bayi berumur 4-6 bulan yang diberikan ASI eksklusif dengan yang tidak diberikan ASI eksklusif. Penelitian ini menggunakan metode penelitian observasional analitik dengan pendekatan cross sectional. Sejumlah 80 bayi berusia 4-6 bulan diambil dengan teknik purposive sampling. Uji statistik yang digunakan adalah Chi Square. Hasil penelitian didapatkan nilai $p=0,000(p<0,05)$ yang artinya terdapat perbedaan signifikan antara status gizi bayi berumur 4-6 bulan yang diberikan ASI eksklusif dengan yang tidak diberikan ASI eksklusif. Diperoleh dari 40 bayi yang diberikan ASI eksklusif mempunyai status gizi lebih baik dibandingkan dengan tidak berikan ASI eksklusif. Status gizi buruk lebih banyak ditemukan pada kelompok bayi yang tidak diberikan ASI eksklusif. Terdapat perbedaan status gizi bayi berumur 4-6 bulan yang diberikan ASI eksklusif dengan yang tidak diberikan ASI eksklusif.
\end{abstract}

Kata Kunci: ASI Eksklusif, ASI Non Eksklusif, status gizi

\section{ABSTRACT}

The coverage of exclusive breastfeeding in Indonesia is only 42\%. Survey in 2013, found that about 19.6\% children in Indonesia suffer from malnutrition. The aim of this study is to explore the difference in nutritional status between infants aged 4-6 months who are exclusively breastfed and those who are not exclusively breastfed. This study used an analytical observational research method with cross-sectional approach. Number of eighty of infantsof 4-6 months old were drawn by purposive sampling technique. Chi-square test was employed as the statistical test. The result showed $p$-value $=0.000(p<0.05)$, which means there is significant difference between the nutritional status of infants aged 4-6 months who are exclusively breastfed and of those who are not exclusively breastfed. It is found that 40 infants who are exclusively breastfed had better nutritional status than those not exclusively breastfed. Poor nutritional status is more common in non-exclusive breastfeeding infant group. There is a difference in nutritional status between infants aged of 4-6 months old who are exclusively breastfed and those who are not exclusively breastfed.

Keywords: exclusive breastfeeding, non-exclusive breastfeeding, nutritional status

\section{PENDAHULUAN}

Perkembangan masalah gizi di Indonesia semakin kompleks saat ini, selain masalah kekurangan gizi, masalah kelebihan gizi juga menjadi persoalan yang harus ditangani dengan serius (Riskesdas, 2015). Ditinjau dari masalah kesehatan dan gizi, balita merupakan periode emas dalam kehidupan anak yang dicirikan oleh pertumbuhan dan perkembangan yang berlangsung pesat serta rentan terhadap kekurangan gizi (Hanum, 2014).
Air susu ibu (ASI) menjadi makanan terbaik di awal kehidupan anak sekaligus hak dasar agar tumbuh dan berkembang secara optimal. Faktor nutrien dan protektif yang sesuai dalam ASI menjamin status gizi baik serta kematian dan kesakitan bayi akan menurun. Zat kekebalan yang terdapat pada ASI antara lain akan melindungi bayi dari penyakit dan menurunkan kemungkinan bayi terkena penyakit infeksi dan alergi (Infodatin Kementrian Kesehatan RI, 2014). 
Hasil penelitian sebelumnya, didapatkan bahwa bayi yang diberikan ASI eksklusif mempunyai pertumbuhan normal lebih banyak daripada bayi yang diberikan ASI non eksklusif. Pada bayi yang mendapatkan ASI eksklusif sebesar $73,3 \%$ pertumbuhannya normal dan $26,7 \%$ pertumbuhannya kurang, sedangkan bayi yang diberikan ASI non eksklusif diperoleh $62,9 \%$ dengan pertumbuhan normal dan 37,1\% adalah pertumbuhan kurang (Fitri $d k k, 2014$ ).

Menurut Riskesdas, pada tahun 2013, terdapat $19,6 \%$ balita kekurangan gizi yang terdiri dari 5,7\% balita dengan gizi buruk dan 13,9\% berstatus gizi kurang. Penyebab utama terjadinya gizi kurang dan hambatan pertumbuhan pada anak usia balita berkaitan dengan rendahnya pemberian ASI. ASI tanpa bahan makanan lain dapat mencukupi kebutuhan pertumbuhan usia sampai sekitar enam bulan. Anak-anak dengan keadaan gizi yang lebih baik berkaitan erat dengan perilaku pemberian ASI, dimana mereka yang sudah tidak diberi ASI lagi ternyata keadaan gizinya lebih rendah (Susanty $d k k, 2012$ ).

Tujuan penelitian ini untuk mengetahui dan menganalisis adanya perbedaan status gizi bayi berumur 4-6 bulan pada pemberian ASI eksklusif dengan ASI non eksklusif.

\section{METODE}

Rancangan Penelitian adalah observasional analitik yang dilakukan dengan metode cross sectional. Penelitian dilakukan di Posyandu Gonilan pada bulan Desember 2015. Populasi pada penelitian adalah bayi berumur 4-6 bulan. Teknik pengambilan sampel adalah purposive sampling, yaitu subjek yang dijadikan sampel telah dipertimbangkan oleh peneliti sendiri (Notoatmodjo, 2012). Besar sampel untuk tiap variabel adalah 37 sampel.

\section{Kriteria Restriksi}

1. Kriteria inklusi

a. Bayi yang berusia 4-6 bulan sehat jasmani

b. Bayi yang tinggal di wilayah sekitar Posyandu Gonilan, Pabelan

c. Ibu bersedia untuk diwawancarai secara lengkap

2. Kriteria eksklusi

a. Bayi 4-6 bulan dengan frekuensi sakit melebihi 5 kali saat bulan pengambilan data

b. Bayi dengan berat badan lahir < $2,5 \mathrm{~kg}$

\section{HASIL DAN PEMBAHASAN}

\section{A. Hasil Penelitian}

Penelitian ini dilakukan di Posyandu Gonilan, Pabelan, Surakarta. Pengamblian data dilakukan pada bulan Desember 2015. Terdapat 80 ibu yang bayinya memenuhi kriteria yang sudah ditetapkan dan bersedia untuk menjadi responden pada penelitian ini.

\section{Analisis Univariat}

\section{a. Distribusi frekuensi pemberian ASI Eksklusif}

Pemberian ASI eksklusif untuk bayi usia 4 bulan - 6 bulan dalam penelitian ini dibuat purposive dengan proporsi yang sama dari 80 bayi usia 4-6 bulan yang diamati. Gambaran pelaksanaan pemberian ASI eksklusif untuk bayi usia 4-6 bulan di Posyandu Gonilan, Pabelan dari hasil penelitian selengkapnya digambarkan pada tabel berikut:

Tabel 1. Distribusi frekuensi pelaksanaan pemberian ASI

\begin{tabular}{llll}
\hline No & Pemberian ASI eksklusif & Jumlah (bayi) & Persentase \\
\hline 1 & ASI Eksklusif & 40 & 50 \\
2 & ASI Non Ekskslusif & 40 & 50 \\
Jumlah & & 80 & 100 \\
\hline
\end{tabular}

Berdasarkan tabel 6 diketahui bahwa dari 80 bayi usia 4-6 bulan yang diberikan ASI eksklusif sebanyak $50 \%$. 


\section{b. Distribusi frekuensi status gizi}

Status gizi bayi ditentukan berdasarkan kriteria berat badan dan panjang badan untuk setiap umur bayi. Seorang bayi diberi status gizi baik apabila berdasarkan berat badan dan panjang badan dalam status baik dan normal. Pada hasil penelitian diperoleh frekuensi status gizi bayi usia 4-6 bulan sebagai berikut :

Tabel 2. Status gizi bayi usia 4-6 bulan menurut BB/U

\begin{tabular}{llcc}
\hline Pemberian ASI & Status gizi & Jumlah (bayi) & Persentase (\%) \\
\hline Eksklusif & Baik & 25 & 31,25 \\
& Tidak Baik & 15 & 18,75 \\
Non Eksklusif & Baik & 20 & 25,0 \\
& Tidak Baik & 20 & 25,0 \\
Total & & 80 & 100.0 \\
\hline
\end{tabular}

Berdasarkan tabel di atas diketahui sebanyak 25 bayi $(31,25 \%)$ mempunyai status gizi baik dari 40 bayi yang diberikan ASI eksklusif. Sementara hanya 20 bayi (25\%) mempunyai status gizi baik dari 40 bayi yang tidak diberikan ASI eksklusif.
Artinya status gizi bayi usia 4-6 bulan pada bayi yang diberikan ASI eksklusif lebih baik dibandingkan bayi yang tidak diberikan ASI eksklusif. Bayi dengan status gizi lebih hampir sama ditemukan pada kelompok bayi yang diberikan ASI eksklusif.

Tabel 3. Status gizi bayi usia 4-6 bulan menurut PB/U

\begin{tabular}{llcc}
\hline Pemberian ASI & Status gizi & Jumlah (bayi) & Persentase (\%) \\
\hline Eksklusif & Baik & 30 & 37,50 \\
& Tidak Baik & 10 & 12,50 \\
Non Eksklusif & Baik & 19 & 23,75 \\
& Tidak Baik & 21 & 26,25 \\
Total & & 80 & 100.0 \\
\hline
\end{tabular}

Berdasarkan tabel di atas diketahui sebanyak 30 bayi $(37,50 \%)$ mempunyai status gizi baik dari 40 bayi yang diberikan ASI eksklusif. Sementara hanya 19 bayi $(23,75 \%)$ mempunyai status gizi baik dari 40 bayi yang tidak diberikan ASI eksklusif. Artinya status gizi bayi usia 4-6 bulan pada bayi yang diberikan ASI eksklusif lebih baik dibandingkan bayi yang tidak diberikan ASI eksklusif. Bayi dengan status gizi lebih hampir sama ditemukan pada kelompok bayi yang diberikan ASI eksklusif.

Analisis Perbedaan antara Status Gizi dengan Pemberian ASI Eksklusif dan ASI Non Eksklusif

Besarnya hubungan antara pemberian ASI eksklusif dengan status gizi bayi usia 4-6 bulan di Posyandu Gonilan, Pabelan digunakan analisis Chi-Square karena memenuhi syarat yaitu nilai expected count $<25 \%$.

Tabel 4. Tabulasi silang hubungan hubungan antara pemberian ASI eksklusif dengan status gizi bayi usia 4-6 bulan dengan perbandingan BB/U di Posyandu Gonilan, Pabelan

\begin{tabular}{lcccc}
\hline Pemberian ASI & \multicolumn{5}{c}{ Status gizi } \\
\cline { 2 - 5 } eksklusif & Baik & Tidak Baik & $\mathrm{X}^{2}$ & $\mathrm{p}$ \\
\hline Eksklusif & 35 & 5 & 16,157 & 0,000 \\
Non Eksklusif & 18 & 22 & & \\
\hline
\end{tabular}

Tabel 4 menunjukan bahwa dari 40 bayi yang diberikan ASI eksklusif mempunyai status gizi lebih baik dibandingkan yang tidak berikan ASI eksklusif. Status gizi tidak baik lebih banyak ditemukan pada kelompok bayi yang tidak diberikan ASI eksklusif. 
Analisis Chi-Square diperoleh nilai value $\mathrm{X} 2$ hitung sebesar 16,157 dengan $\mathrm{p}=0,000 \quad(\mathrm{p}<0,05) \quad$ sehingga hipotesa diterima yang berarti ada perbedaan signifikan antara pemberian ASI eksklusif pada bayi usia 4-6 bulan di Posyandu Gonilan, Pabelan dengan status gizinya.

Tabel 5. Tabulasi silang hubungan hubungan antara pemberian ASI eksklusif dengan status gizi bayi usia 4-6 bulan dengan perbandingan PB/U di Posyandu Gonilan, Pabelan

\begin{tabular}{ccccc}
\hline Pemberian ASI & \multicolumn{5}{c}{ Status Gizi } \\
\cline { 2 - 5 } eksklusif & Baik & Tidak Baik & $\mathrm{X}^{2}$ & $\mathrm{p}$ \\
\hline Eksklusif & 30 & 10 & 16,157 & 0,000 \\
Non Eksklusif & 19 & 21 & & \\
\hline
\end{tabular}

Tabel 10 menunjukan bahwa dari 40 bayi yang diberikan ASI eksklusif mempunyai status gizi lebih baik dibandingkan yang tidak berikan ASI eksklusif. Status gizi tidak baik lebih banyak ditemukan pada kelompok bayi yang tidak diberikan ASI eksklusif.

Analisis Chi-Square diperoleh nilai value $\mathrm{X} 2$ hitung sebesar 16, 157 dengan $\mathrm{p}=0,000 \quad(\mathrm{p}<0,05) \quad$ sehingga hipotesa diterima yang berarti ada perbedaan signifikan antara pemberian ASI eksklusif pada bayi usia 4-6 bulan di Posyandu Gonilan, Pabelan dengan status gizinya.

\section{B. Pembahasan}

Hasil penelitian menunjukkan masih terdapat bayi yang tidak diberikan ASI eksklusif sehingga dalam penelitian ini diambil proporsi berpasangan $50 \%$ untuk bayi yang diberikan ASI eksklusif dan $50 \%$ untuk bayi yang tidak diberikan ASI eksklusif.

Secara umum status gizi bayi usia 4-6 bulan di Posyandu Gonilan, Pabelan berstatus gizi baik, yaitu sebanyak 54 bayi dari 80 bayi yang diamati. Status gizi lebih ditemukan lebih banyak pada bayi usia 4-6 bulan yang tidak diberikan ASI eksklusif. Hasil ini sesuai dengan temuan Khasanah (2011) yang menyimpulkan pada umumnya bayi usia 4-6 bulan yang mendapat susu formula mengalami kenaikan berat badan yang lebih cepat dibanding dengan bayi yang diberi ASI eksklusif. Kelebihan berat badan pada bayi yang mendapat susu formula karena kelebihan kandungan air dan komposisi lemak. Pada beberapa susu formula sumber protein dan lemaknya berasal dari susu sapi.

ASI merupakan makanan yang ideal secara fisiologis dan biologis bagi bayi dan dapat memenuhi kebutuhan gizi bayi pada usia
4-6 bulan pertama.Pemberian MP ASI sebelum bayi berusia 4 bulan mengakibatakan kenaikan berat badan yang lebih rendah dan kurang gizi dibandingkan dengan bayi yang tetap diberi ASI eksklusif sampai usia 6 bulan. Masih dijumpai kebiasaan yang salah dalam pemberian ASI dan MP ASI. MP ASI yang diberikan terlalu dini dapat berdampak pada status gizi (Haileslassie, et al., 2013).

Hasil analisis statistik diketahui ada perbedaan antara pemberian ASI eksklusif dengan status gizi bayi usia 4-6 bulan di Posyandu Gonilan, Pabelan $(p<0,05)$. Hal ini sesuai dengan temuan Khasanah (2011) yang menyimpulkan pada bayi usia 0-6 bulan zat gizi yang dibutuhkan oleh bayi dapat dipenuhi dengan pemberian ASI secara eksklusif

Hasil analisis statistik diketahui ada perbedaan antara pemberian ASI eksklusif dengan status gizi bayi usia 4-6 bulan di Posyandu Gonilan, Pabelan $(p<0,05)$. Hal ini sesuai dengan temuan Khasanah (2011) yang menyimpulkan pada bayi usia 0-6 bulan zat gizi yang dibutuhkan oleh bayi dapat dipenuhi dengan pemberian ASI secara eksklusif

Hasil penelitian ini didukung temuan Aziezah dan Adriani (2013), yang menyatakan dari hasil status gizi bayi, dapat diketahui bahwa bayi yang mendapatkan ASI eksklusif seluruhnya memiliki status gizi baik yaitu sebesar 100\% sedangkan bayi yang tidak mendapatkan ASI eksklusif memiliki status gizi baik hanya 58,80\%. Hal ini dikarenakan jumlah kandungan kalori yang ada pada ASI eksklusif berbeda dengan kandungan susu formula. Air susu ibu mengandung protein khusus yang dirancang untuk pertumbuhan bayi. Protein yang terdapat pada ASI dan susu sapi terdiri dari protein whey dan casein. 


\section{SIMPULAN}

Terdapat perbedan yang signifikan antara status gizi bayi berumur 4-6 bulan yang diberikan ASI Eksklusif dan ASI non eksklusif di Posyandu Gonilan Kartasura.

\section{DAFTAR PUSTAKA}

Aziezah, N., Adriani, M., 2013. Perbedaan Tingkat Konsumsi dan Status Gizi Antara Bayi dengan Pemberian ASI Eksklusif dan Non ASI Eksklusif. Media Gizi Indonesia. Vol.9 No.1 hlm:78-83.

Fitri, DI., Chundrayetti E, Semiarty R. 2014. Hubungan Pemberian ASI dengan Tumbuh Kembang Bayi Umur 6 Bulan di Puskesmas Nanggalo. Jurnal Kesehatan Andalas 2014; 3(2). (diunduh 15 Juni 2015) Tersedia dari: URL: HYPERLINK http://jurnal.fk.unand. ac.id/index.php/jka/article/download/51/46

Hanum, F., Khomsan, A., \& Heryatno, Y. 2014. Hubungan Asupan Gizi dan Tinggi Badan Ibu dengan Status Gizi Anak Balita. Jurnal Gizi dan Pangan, 9(1). http:// journal.ipb.ac.id/index.php/jgizipangan/article/ viewFile/8256/6458. asi Hanum 8256-232511-PB.pdf. (2015.09.15)

Haileslassie, K, Mulugeta A, Girma M.., 2013. Feeding practices, nutritional status and associated factors of lactating women in Samre Woreda, South Eastern Zone of Tigray, Ethiopia. Nutrition Journal 2013. $12: 28$
Kementrian Kesehatan RI., 2013. Penyajian Pokok-Pokok Hasil Riset Kesehatan Dasar 2013. Jakarta: Kementrian Kesehatan RI

Strategis Kementrian Kesehatan Tahun 2015-2019. Jakarta : Kementrian Kesehatan RI

Khasanah, N. 2011. ASI atau Susu Formula Ya?. Panduan Lengkap Seputar ASI dan Susu Formula . Yogyakarta: Flashbook

Notoadmojo, S., 2012. Kesehatan Masyarakat Ilmu dan Seni. Jakarta: Rineka Cipta.

Pusat Data dan Informasi Kementrian Kesehatan RI., 2014. Situasi dan Analisis ASI Eksklusif 2014. Jakarta : Kementrian Kesehatan RI

Susanty, M, Kartika M, Hadju V,\& Alharini S. 2012. Hubungan Pola Pemberian Asi dan Mp Asi Dengan Gzi Buruk Pada Anak 6-24 Bulan Di Kelurahan Pannampu Makassar. Jurnal Media Gizi Masyarakat Indonesia 2012; 2(1): 97-103. (diunduh 22 Juni 2015). Tersedia dari: URL: HYPERLINK http://journal.unhas.ac.id/index.php/mgmi/ article/view/427 